\title{
Investigation of the structure and hardness of quenched sintered materials produced from iron-base alloyed powders (Astaloy $\mathrm{E}$ )
}

\begin{abstract}
The effect of heat treatment on the microstructure, hardness and density of sintered $\left(1129^{\circ} \mathrm{C}\right.$, $45 \mathrm{~min}$ ) specimens of iron-base powder alloys containing $0.8-2.5 \% \mathrm{C}, 2 \% \mathrm{Cu}$ and additives of chromium- and molybdenum-alloyed Astaloy E iron powder is studied.
\end{abstract}

Keyword: Powder metallurgy; Sintering; Iron powder; Heat treatment 